\title{
Development and Characterization of Parian Bodies Using Feldspar from Two Selected Deposits in Nigeria
}

\author{
Toluwalope OGUNDARE ${ }^{1 *}$, Oluwagbenga FATILE ${ }^{2}$ Olusola AJAYI $^{3}$ \\ ${ }^{1,2,3}$ Department of Glass and Ceramic Technology \\ Federal Polytechnic Ado Ekiti, Ekiti State, Nigeria
}

Geliş Tarihi: 2015-12-10 Kabul Tarihi: 2016-04-01

\begin{abstract}
Self glazed bodies also called Parian Bodies are chiefly composed of Feldspar which majorly acts as flux in reducing the melting temperature of the particular ceramic body thereby reducing the stress of double firing a ceramic product. In this present research work, Okpella and Ijero-Ekiti feldspar deposits in Nigeria together with other raw materials were utilized to develop parian bodies which are very suitable for making ceramic tiles, dolls and figurines. Chemical analyses were carried out on the raw materials using X-ray fluorescence (XRF) in order to ascertain their suitability for developing parian bodies. Six compositions were made from these two deposits using a standard parian body composition of $70 \%$ feldspar. The samples were shaped, dried and sintered between $1050{ }^{\circ} \mathrm{C}-1250{ }^{\circ} \mathrm{C}$ at the interval of $50^{\circ} \mathrm{C}$. Flexural strength, fired shrinkage, porosity and water absorption tests were used to characterize the samples. The results showed that samples fired at $1200^{\circ} \mathrm{C}$ and $1250^{\circ} \mathrm{C}$ exhibited technological properties that meet up with ISO standards. The two feldspar deposits were found to be suitable for developing parian bodies.
\end{abstract}

Keywords: Parian, Feldspar, Kaolin, Porcelain, Sintered, Whiteware.

\section{Introduction}

Recently, the development of self glazed porcelain ware is attracting interest from researchers in Ceramic Technology field owing to their technological properties and low cost of production. Porcelain bodies are usually made up of at least three components that play the three fundamental roles for optimum processing, and hence performance of the final products, kaolin or kaolinitic clay for plasticity, feldspar for fluxing and silica as filler for the structure [1]. The thermal, dielectric and mechanical properties of the products can be improved by varying the proportions of the three main ingredients [2]. The main differences between compositions are in the relative amounts and kinds of raw materials used. Most times, it is observed that an increasing amount of feldspar added to porcelain body composition usually results in formation of liquid phase at the eutectic temperature, which increases the degree of vitrification and translucency at lower temperature [3]. As feldspar is replaced by clay, higher temperatures are required for vitrification due to the introduction of a more refractory material, and the firing process becomes more difficult and expensive. However, the forming processes become easier, and the mechanical properties of the resulting body are improved [4]. Porcelain happens to be a class of whiteware, which is distinguished from the other class by its firing temperature, composition and mainly by the lack of open porosities on the fired body, but self glazing effect can be achieved from porcelain bodies with introduction of high quantity of fluxes. This self glazing ceramic ware is known as "Parian" and has been achieved by introducing certain fluxes like feldspar which when fired at high temperatures contributes to the formation of a thin layer of glass fused at the ware surface. This glass film has a very similar composition to the respective ceramic material and prevents the hairline cracks known as crazing. Parian is extremely translucent through a large temperature range and ideally suited for casting to produce figurines, dolls and light forms. This body is chiefly made up of very white feldspar which uses a floatation method of particles distribution and some frothing may occur due to high speed of mixing. Parian was a development of earlier biscuit porcelain, but has higher proportion of feldspar in body composition than the normal porcelain, makers fired it at a lower temperature and the high content of feldspar present in the body will make the fired ware to be more vitrified, thus possessing a colour verging on ivory and having a marble like structure that is smoother than that of biscuit or glazed ware. When parian bodies are made, they come out faint but extremely

*Corresponding author: Toluwalope OGUNDARE, Address: Department of Glass and Ceramic Technology Federal Polytechnic Ado Ekiti, Ekiti State, Nigeria, E-mail Address: t_ory2003@yahoo.com, Phone: 2348038058132 
beautiful[5]. Parian is a creamy white, semitranslucent type of porcelain with a granular marble like texture. Parian unique marble- like texture is achieved by using a high percentage of feldspar [6]. Parian when made comes out translucent with a fine granular surface and has a china resembling marble like in texture, Its invention did not come out of thin air however it's a product of individuals who attempted to find a warmer creamier material more like marble from which they could mould decorative items. A self- glaze clay, so once fired, it has a slight shine/ shimmer to it. It is fine to go straight on to the kiln shelf, however does stick to it is own body if slabs are placed on top of one another during the firing. Self- glaze actions take place when the composition is fired. Parian body is constituted in form of a glass for producing a selfglazed ceramic body which include the step of performing a structure consisting essentially of ceramic powder having a firing temperature with the range from $1150^{\circ} \mathrm{c}-1250^{\circ} \mathrm{c}$ consisting essentially $70 \%$ of feldspar [6]. Feldspar is a very common mineral found naturally in most primary rock in amount up to $60 \%$. Its function is generally applicable as a flux in clay and glazes many different types of feldspar exist, the main groups are potash and soda. Feldspar can be recognized by its pearly luster and opaque appearance. The crystal has too main cleavages that are nearly at right angles to each other [7].

Basically, the two properties which make feldspar useful for downstream industries are their alkali and alumina content. On those elements we can distinguish three families; feldspathic sand, pegmatite and feldspar. A further distinction can be made between sodium, potassium and mixed feldspars depending on the type of alkali they contain. In glass production feldspar is an important ingredient and an imperative raw material as well because it acts as fluxing agent, reducing the melting temperature of quartz and helping to control the viscosity of glass. The alkali content in feldspar acts as flux thereby lowering the glass batch melting temperature and thus reducing production cost. In ceramics feldspar is the second most important ingredient after clay, feldspar does not have a strict melting point since it melts gradually over a range of temperatures. This greatly facilitates the melting of quartz and clays and through appropriate mixing allows modulation of this important step of ceramic making. Feldspar also improves the strength, toughness and durability of the ceramic body. Feldspar assist the enamel composition assuring the absences of defects and neatness of the end product e.g. enamel frits, ceramic glazes, ceramic tiles glazes, sanitary ware, table ware, electrical porcelain and gift ware. In the flooring sector, feldspar is the main constituent in the body composition. It is used as a flux, lowering the vitrifying temperature of ceramic body during firing and forming a glassy phase. In table ware feldspar gives a good fusibility for a product without defects. In sanitary ware, the use of feldspar within vitreous ceramic bodies facilitates the optimization process [8].

Despite the fact that parian bodies have numerous advantages over non self glazed bodies, insufficient attentions have been devoted to development and characterization of parian bodies. This work is part of current efforts aimed at considering the potentials of numerous feldspar deposits around the world as suitable raw material in making parian bodies for low cost production of ceramic wares.

\section{Material and method}

The raw materials selected for this research work are Feldspar from Okpella in Edo State, Feldspar from Ijero-ekiti in Ekiti State, ball clay, kaolin and flint. All the raw materials were sourced from Nigeria. Chemical analysis was carried out on the raw materials using X-ray fluorescence spectroscopy. The result of the chemical composition is as presented in Table 1. Six different body compositions were formulated by using $70 \%$ of Feldspar in each of the samples and varying the percentage of other raw materials as shown in Table 2.

\section{Preparation of samples}

The processed raw materials were weighed according to the composition in table 2 using accurate electronic weighing balance. The weighed raw materials were charged into pot mill containing porcelain grinding media (pebbles) and $35 \%$ water of the total charge was added together with sodium tripoliphosphate as deflocculant. The pot mill was allowed to run for two hours before its content was discharged into a dry pan. The pan and its content were dried in electric oven at the temperature of $110^{\circ} \mathrm{C}$ for two hours. The dried material was then crushed and $7 \%$ weight of water was added before passing through a 100 mesh $(150 \mu \mathrm{m})$ to obtain suitable powders for pressing. Each composition were used to produce samples of tiles of size $100 \mathrm{~mm} \times 100 \mathrm{~mm} \times 10 \mathrm{~mm}$ by using uniaxial hydraulic pressing machine at the pressure of 50bars. The samples were allowed to dry for 24 hours before drying in laboratory oven at $110^{\circ} \mathrm{C}$ for two hours after which they were sintered in an electric kiln at different temperature of $1050^{\circ} \mathrm{C}$, $1100^{\circ} \mathrm{C}, 1200^{\circ} \mathrm{C}$ and $1250^{\circ} \mathrm{C} \mathrm{C}$ (heating and cooling rates of $5^{0}$ per minute), and with soaking time of 1 hour at the maximum temperature. 


\section{Characterization of the samples}

The samples produced were characterized using standard methods in order to determine their technical properties. The shrinkage test was carried out on the samples by determining the initial length before firing (Lo) and the length after firing $\left(\mathrm{L}_{\mathrm{f}}\right)$ using digital venier caliper. The Percentage linear shrinkage was determined using equation (1).

$\%$ Linear Shrinkage $=\frac{\text { Lo }- \text { Lf }}{\text { Lo }} \times 100$

Table 1: Chemical Composition of Raw Materials (wt. \%)

\begin{tabular}{|c|c|c|c|c|c|c|c|c|c|}
\hline \multirow[t]{2}{*}{ Material } & \multicolumn{9}{|c|}{ Oxides (wt. \%) } \\
\hline & $\mathrm{SiO}_{2}$ & $\mathrm{Al}_{2} \mathrm{O}_{3}$ & $\mathrm{CaO}$ & $\mathrm{Na}_{2} \mathrm{O}$ & $\mathrm{Fe}_{2} \mathrm{O}_{3}$ & $\mathrm{~K}_{2} \mathrm{O}$ & $\mathrm{MgO}$ & $\mathrm{MnO}$ & LOI \\
\hline $\begin{array}{l}\text { Ijero } \\
\text { Feldspar }\end{array}$ & 66.47 & 18.20 & 0.65 & 2.84 & 0.33 & 9.61 & 0.25 & - & - \\
\hline $\begin{array}{l}\text { Okpella } \\
\text { Feldspar }\end{array}$ & 65.98 & 14.62 & 0.95 & 3.62 & 0.76 & 8.87 & 0.29 & - & - \\
\hline Kaolin & 48.21 & 33.36 & 0.23 & 0.13 & 0.74 & 0.77 & 0.05 & - & 12.83 \\
\hline Quartz & 96.12 & 1.17 & 0.11 & 0.62 & 0.12 & 0.20 & 0.07 & - & 3.84 \\
\hline Ball Clay & 44.82 & 37.35 & 0.07 & 0.11 & 1.09 & 0.89 & 0.12 & - & - \\
\hline
\end{tabular}

Table 2: Formulation of the Samples (Wt. \%)

\begin{tabular}{|l|l|l|l|l|l|}
\hline & Okpella Feldspar & Ijero Feldspar & Flint & Kaolin & Ball Clay \\
\hline A & 70 & & & 30 & \\
\hline B & 70 & & 10 & 20 & \\
\hline C & 70 & & 10 & & 20 \\
\hline D & & 70 & & 30 & \\
\hline E & & 70 & 10 & 20 & \\
\hline F & & 70 & 10 & & 20 \\
\hline
\end{tabular}

The flexural strength was determined using a universal testing machine (MTS $810.23 \mathrm{M}$ ), in three-point bending fixture, $70 \mathrm{~mm}$ support span and with a crosshead speed of $50.5 \mathrm{~mm}$ min-1.

Porosity and water absorption were determined using boiling method.The specimen were subjected to 1 hour boiling followed by an additional two hour water soaking and then weighed as $\mathrm{W}_{\text {sat }}$. The soaked specimen were then suspended from the beam of a balance in a vessel of water in such a way that specimen were completely immersed in the water without touching the side of the vessel. Weights of the suspended specimen were determined as $\mathrm{W}_{\text {sus. }}$. The specimen were dried in oven for 24hours and the weight were determined as $\mathrm{W}_{\mathrm{d}}$. The test was carried out on four representative specimens. Percentage porosity and water absorption were calculated using equation 2 and equation 3 respectively.

$$
\begin{aligned}
& \text { Porosity }=\frac{\text { Wsat-Wd }}{\text { Wsat-Wsus }} \times 100 \text { (2) } \\
& \text { Water absorption }=\frac{\text { Wsat }- \text { Wd }}{W d} \times 100
\end{aligned}
$$

\section{Results and discussion}

Result of the linear shrinkages after firing at different temperatures is as presented in figure
1.The linear shrinkage indicates the degree of densification during firing, and it is very important for the dimensional control of the ceramic products. It is observed from figure 1 that linear shrinkage values of the samples were within the range of $2.4 \%-10.4 \%$. These values are within the safe limits for industrial production of self glazed porcelain products. Generally, it is observed that the linear shrinkage of the samples increased with increase in temperature with samples sintered at $1200^{\circ} \mathrm{C}$ exhibiting the highest linear shrinkage with the exception of sample A and F. It is also observed that sample $\mathrm{C}$ exhibited the highest linear shrinkage at all temperatures in comparison with other samples.

Figure 2 also shows the results of water absorption tests carried out on the samples. From figure 2, it is observed that the water absorption generally decreased with increase in firing temperature with samples fired at $1250^{\circ} \mathrm{C}$ exhibiting the lowest water absorption values. The decrease in water absorption values at high temperature could be attributed to the formation of more liquid phase that mainly originated from the feldspar. The liquid phase aids sintering which resulted in maximum vitrification at high temperature. This behaviour is similar to that showed by nearly all porcelain bodies [2].

All the samples fired at $1200^{\circ} \mathrm{C}$ and $1250^{\circ} \mathrm{C}$ had water absorption values within the range of $0.1 \%$ - 
$0.5 \%$.This implies that all the samples fired at $1200^{\circ} \mathrm{C}$ and $1250^{\circ} \mathrm{C}$ meet up with ISO standard which recommended water absorption value of not greater than $0.5 \%$ for porcelain tiles. The result is also in agreement with previous work reported by other authors [1,9].

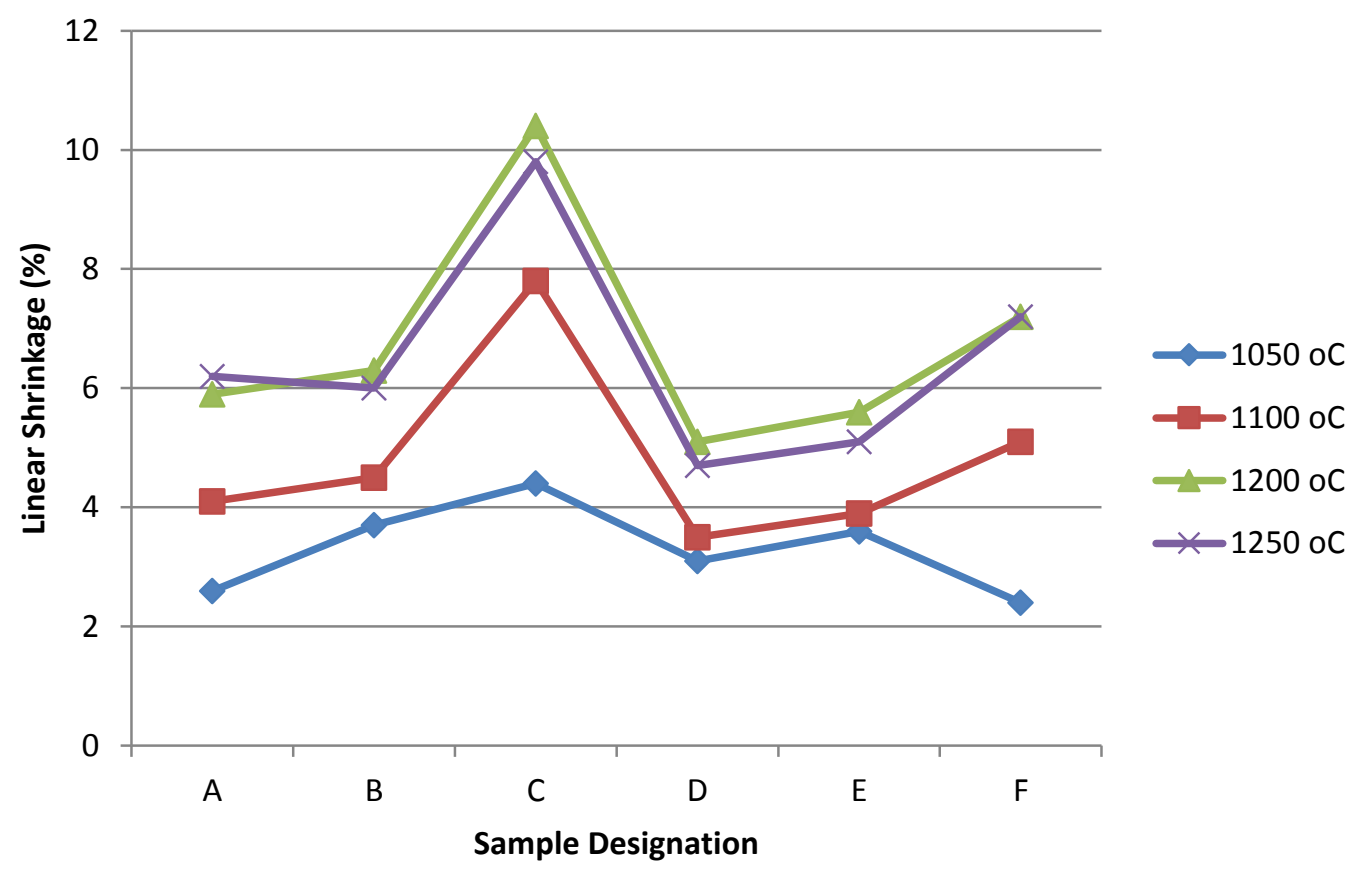

Figure 1. Linear shrinkage of samples sintered at different temperature

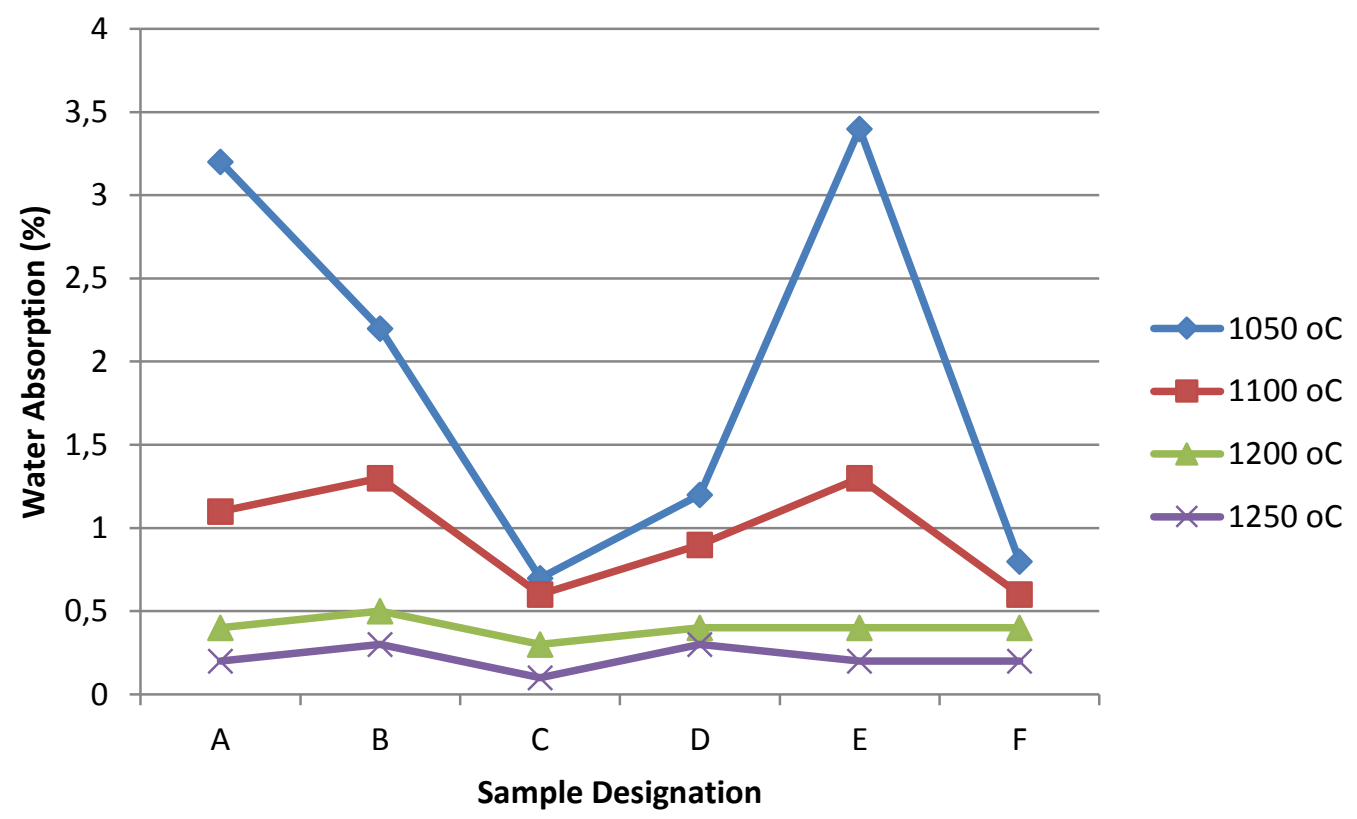

Figure 2. Water absorption of samples sintered at different temperature 


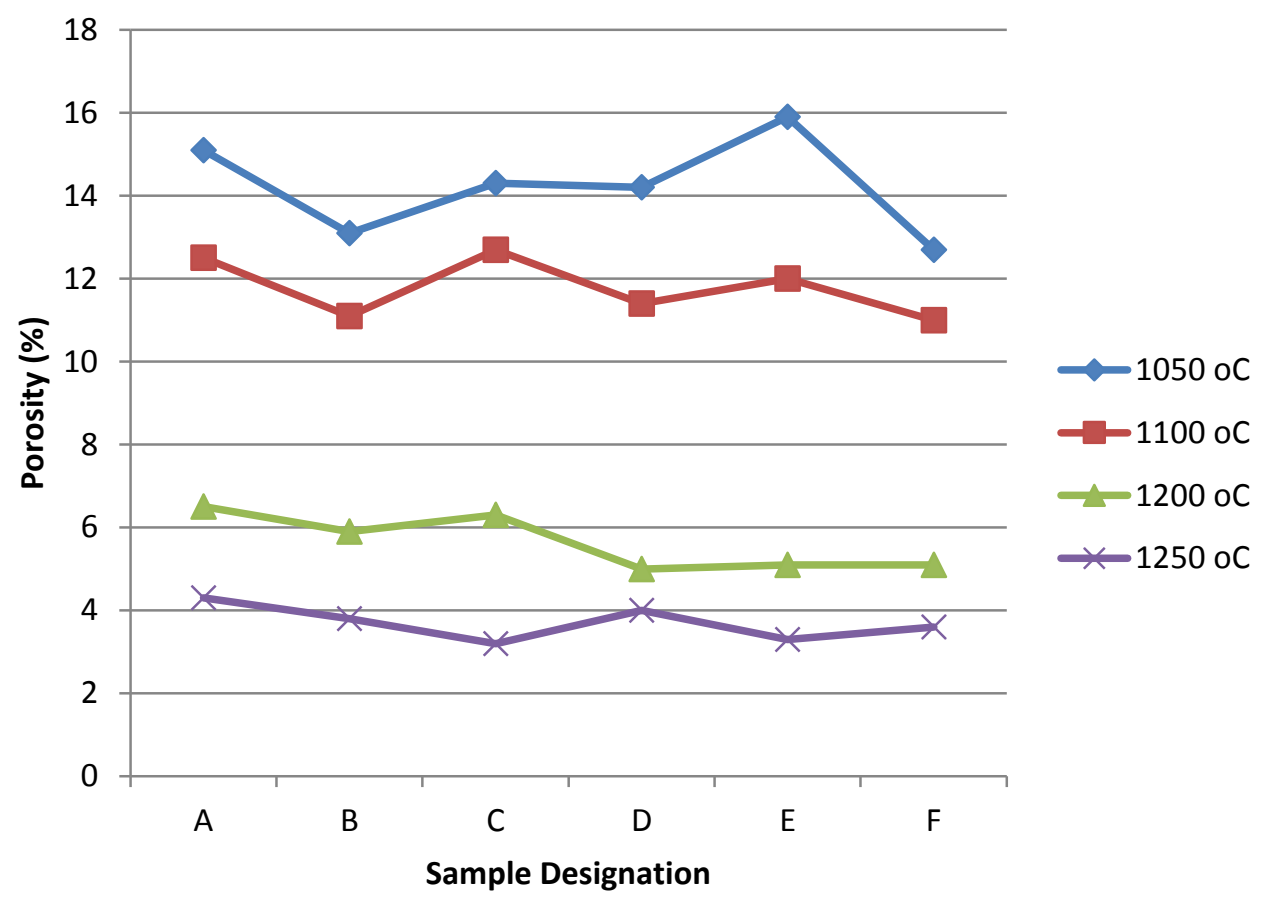

Figure 3. Porosity of samples sintered at different temperature

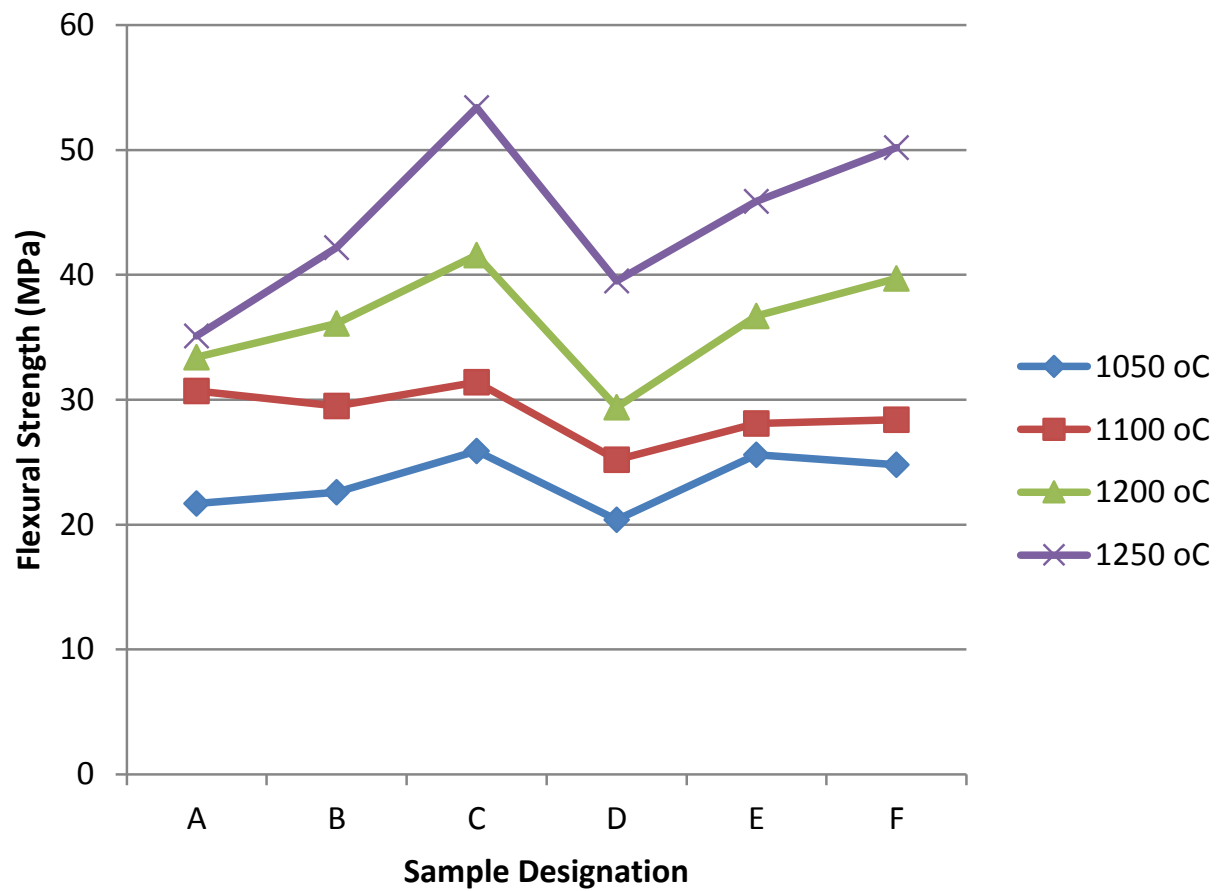

Figure 4. Flexural strength of samples sintered at different temperature

The result of porosity tests carried out on the samples is as presented in figure 3 . Porosity of the fired samples is associated to other properties such as water absorption and linear shrinkage. The result followed the same trend with that of water absorption rate. From figure 3 , it is generally observed that the percentage porosity value of the samples decreased with increase in sintering temperature. Martin-Marquez et al [10] have reported that optimum vitrification range is achieved in porcelain tiles when open porosity reaches a minimum value, tending to be nearly zero, and simultaneously linear shrinkage is maximum. 
The result of bending strength test of the samples sintered between $1050^{\circ} \mathrm{C}$ and $1250^{\circ} \mathrm{C}$ is as presented in figure 4 . The result shows that the flexural strength values of the samples are within the range of 20.4Mpa-53.4Mpa. From figure 4, it is generally observed that the flexural strength of the samples increased with increase in firing temperature with sample $\mathrm{C}$ exhibiting the highest flexural strength values at all temperature in comparison with other samples. The high flexural strength values exhibited by sample $\mathrm{C}$ at all temperature are also consistence with the water absorption values. Boussak et al. [11] have reported that increase in temperature of ceramic compositions containing clays and feldspars result in higher mullite formation, thereby improving mechanical properties.

Although, sample $\mathrm{C}$ and $\mathrm{F}$ contained $70 \%$ of Okpella feldspar and Ijero feldspar respectively but chemical analyses of the two feldspar samples showed Okpella feldspar contains more fluxes in comparison with Ijero feldspar. The higher percentage of fluxes in Okpella feldspar contributed to formation of more liquid phase in sample $\mathrm{C}$ which enhanced its vitrification and flexural strength in comparison with sample F. According to ISO standard, the minimum flexural strength value recommended for porcelain tiles is $35 \mathrm{Mpa}$. This implies that nearly all the samples fired at $1200^{\circ} \mathrm{C}$ and $1250^{\circ} \mathrm{C}$ meet up with ISO standard with the exemption of sample A and D fired at $1200^{\circ} \mathrm{C}$.

\section{Conclusions}

The development and characterization of parian body using feldspar from two selected deposits in Nigeria was successfully investigated. The results show that:

- The percentage linear shrinkage of the samples increased with increase in firing temperature with sample $\mathrm{C}$ exhibiting the highest linear shrinkage.

- All the samples fired at $1200^{\circ} \mathrm{C}$ and $1250^{\circ} \mathrm{C}$ had water absorption values of not greater than $0.5 \%$ which is the required standard for porcelain tiles according to ISO.

- All the samples fired at $1200^{\circ} \mathrm{C}$ and $1250^{\circ} \mathrm{C}$ had flexural strength values of not less than $35 \mathrm{Mpa}$ with the exemption of sample A and D.

- Sample C and F fired at $1200^{\circ} \mathrm{C}$ and $1250^{\circ} \mathrm{C}$ produced the best self glazed body which also meet up with require standards.

\section{References}

[1] Kamseu E., Leonelli C., Boccaccini D.N., Veronesi P., Miselli P., Giancarlo P. and Chinje M.U., Characterisation of Porcelain Compositions Using Two China Clays from Cameroon, Ceramics International, 2007, 33, p. 851-857.

[2] Peter W.O., Stefan J. and Joseph K.B., Characterization of Feldspar and Quartz Raw Materials in Uganda for Manufacture of Electrical Porcelains, Journal of Australia Ceramic Society, 2006, 41(1), p. 29-35.

[3] Reed, J.S., Principles of Ceramics Processing, New York, Wiley \& Sons, 1995.

[4]McLaren E. A. and Cao P. T. Ceramics in Dentistry-Part I: Classes of Materials. Inside Dentistry; 2009.

[5] Carty, W.M., 2002, Observation on the Glass Phase Composition in Porcelains. Chem. Eng. Sci. Proc., 2002, 23(2), p. 79-94.

[6] Holdren, G.R and Berner, R.A, Mechanism of Feldspar Weathering.

low Temperature Feldspars in Sedimentary Rocks, American Journal of Science, 1999, p. 279, 435479.

[7] Ima (2000). Ceramic Raw Materials. London Pergarmon Press.

[8] Nelson,I and Stephen, A (2008): Weathering and Clays minerals.

[9] Matthew G.O., and Fatile B.O., Characterization of Vitrified Porcelain Tiles Using Feldspar from Three Selected Deposits in Nigeria. Research Journal of Recent Sciences, 2014, 3(9), p. 67-72.

[10] Martín-Márquez J., Rincón M.J. and Romero M., Effect of firing temperature on sintering of porcelain stoneware tiles, Ceramics Internacional, 2008, 34, p. 1867-1873.

[11] Boussak H., Chemani H., and Serier A., Characterization of Porcelain Tableware Formulation Containing Bentonite Clay, International Journal of Physical Sciences, 2014, 10(1), p. 38-45. 